\title{
MATHEMATICS TEXTBOOK ANALYSIS IN TERMS OF SUPPORT TO CONTEXTUALIZED TEACHING
}

\author{
Dragica Milinković $^{1 \star}$, Milenko Ćurčić ${ }^{2}$ and Tatjana Dumitrašković ${ }^{3}$ \\ ${ }^{1}$ Assoc. Prof. Dr., University of East Sarajevo, Bosnia and Herzegovina, sadra@teol.net \\ ${ }^{2}$ Prof. Dr., University of East Sarajevo, Bosnia and Herzegovina, ljekobilje@teol.net \\ ${ }^{3}$ Assist. Prof. Dr., University of East Sarajevo, Bosnia and Herzegovina, \\ tatjana.dumitraskovic@pfb.ues.rs.ba \\ ${ }^{*}$ Corresponding author
}

\begin{abstract}
In the process of teaching mathematics in the primary school cycle in the Republic of Srpska, the textbook has a very important role, considering its focusing effect on the learning and teaching, that is to say, on the structure of students' mathematical knowledge. In this sense, the use of textbooks in initial teaching of mathematics, particularly in the design and implementation of the process of teaching, is one of the important indicators of the mode of work and the place of students and teachers in the educational process.

This paper research points out the necessity of aligning the textbook concept with modern theories of mathematics education, including the creation and writing of textbooks that will serve the realization of achieving goals of modern mathematics teaching. Among other things, the textbook model that will meet set requirements will feature the representation methods, procedures, and teaching approaches that promote active and interactive learning, as well as, creative and critical thinking. The paper also points out the contemporary tendencies that new models of textbooks should be primarily based on contextualization, which implies a problem solving approach to teaching and the development of higher forms of learning and thought processes. This context is the starting point for empirical analysis with the aim to test the support for standard math textbooks for junior grades of elementary school approved for use in the Republic of Srpska in school year 2016/2017, and the process of contextualization of learning and teaching mathematics in elementary school teaching. In the first part of the paper, the theoretical aspects of the fundamental concepts of contextual teaching and learning in mathematics teaching in junior grades of elementary school, as well as the importance of the textbooks in acquiring knowledge are shown. The first part of the paper also deals with the analysis of current textbooks focusing especially on the elements of the contextual approach to the process of teaching.

The second part of the paper deals with explaining numeric indicators, which indicate that in the textbooks of mathematics from the first to the fifth grade different modes of contextual problems are identified primarily with regard to different forms of expression and presentation (illustrated, textual, combined - picture, text). The results of their number indicate the unsatisfactory support of standard textbooks to the process of contextualization of learning and teaching mathematics in junior grades of elementary school teaching, since textbook context, both in terms of sources of information, and methodical scenarios have dominant transmissive role in teaching mathematics.
\end{abstract}

Keywords: Contextualization, Learning, Mathematics, Teaching, Textbook. 


\section{INTRODUCTION}

The textbook, with respect to its development and formative role, is considered to be an important component of teaching and learning, that is to say, of the construction of students' knowledge. Therefore, it is an indicator of the quality of work in mathematics teaching in the basic school cycle and the use of textbooks in various stages of the educational process. Keeping in mind the demands of modern methods of teaching mathematics in terms of alignment of teaching process with modern theories of mathematics education, there is a need to create and write a textbook that will, among other things, feature representation of methods, procedures and approaches that promote active and interactive learning, and creative and critical thinking.

As the teaching of mathematics in teaching process of the basic school cycle is essentially conditioned by the situation and developments in the context of the external environment and internal mental state of each individual student, the focus is on contextual approach to teaching mathematics. Research show that the acquisition of mathematical knowledge, that is to say, teaching and learning out of the context is very difficult and boring to students while the knowledge acquired out of the broader context of thematic groups to which they belong, is difficult to be generalized, and it is also not permanent enough and not easily usable.

Since learning mathematics in lower grades of elementary school cannot proceed independently, in isolation from the particular context of real life, without the influence of prior knowledge and experience of students, their beliefs, ways of thinking, understanding and the like, it is necessary to base initial mathematical education on the principles of contextual learning and teaching. In this sense, the focus is primarily on the tendency for new models of textbooks to be based on contextualization, which implies a problem solving approach to teaching and the development of higher forms of learning and thought processes.

\section{THEORETICAL APPROACH TO THE RESEARCH PROBLEM}

\subsection{Contextualization of learning and teaching mathematics}

Although, practically speaking, the emergence of contextual learning terminology is associated with the emergence of learning in general, the originator of the idea of contextual approach to teaching and learning in the teaching process is J. Dewey. His school at the University of Chicago, founded in 1896, embodied many of the principles of contextual learning, primarily "the idea that there is an inseparable link between empirical learning and education" (Dewey, 1963: 20). Contextual teaching and learning, as the theory and system of education first introduced the Russian scientist A. A. Verbitsky in 1981, who emphasized its foundation in psychology through which it came into education.

Researchers from different scientific fields dealt with studying the contextual learning and teaching and accordingly, they treated it and conceptually determined it in a different way. Taking into account the different views and functions of contextual teaching and learning, it was "written about", and it was developed as a range of principles and methods, methodological framework, psychological and methodological approach, strategy, system (Johnson, 2002), theory (Verbitsky, 1991), conception (Berns, Erickson, 2001), and the project of particular importance for education (Rogers, Weinbaum, 1995). Despite the differences the mentioned authors are unanimous that contextual teaching and learning primary implies the connection of teaching content and learning with context in which to use the content, which implies the integration of educational and practical activities of students and the need to overcome the separation of theoretical from the practical knowledge. Consequently, they see the process of teaching as the process of education in which, the main goal should be the teaching of students to detect the meaning of the content they learn linking this content with social, cultural and business context, and the context of everyday life.

An adequate teaching context to enable the achievement of the above goal in the teaching of mathematics of the basic school cycle involves the implementation of methods, strategies and approaches to the process of teaching which include experiential learning in an authentic context. Preference is given to problem-oriented and situational models of active and interactive teaching mathematics which, in interaction strategies for learning and teaching, students' characteristics and teaching context, contributes directly to the achievement of learning outcomes and teaching goals. As the teaching context plays an important role in connecting mathematics content with meaning and significance of this content, it is necessary to modify it to the students to engage them in activities through a contextual approach to teaching which as a result has contextual learning and teaching.

De Lang specifies three levels of using context in mathematics education, emphasizing their impact on defining the role of the context in learning and teaching of mathematics: 
1. using context in solving "simpler" problems (easy transferring the original problem into a mathematical one) and in performing mathematical operations that are built into it (often found in traditional textbooks);

2. using context in the creation of relevant mathematical situations;

3. using context to develop mathematical models and concepts (De Lange, 1987: 76-77).

In initial mathematics teaching the context of learning in teams and groups representing specific environment for each individual is emphasized since it consists of students of different skills, experience, attitudes, interests ... Such a composition of the community, with all the individualities of those who constitute it , their

E. Johnson (2002) gives the most comprehensive demonstration of the practical benefits of contextual teaching and learning. She emphasizes interdependence, differentiation and self-organization as universal scientific principles the contextual teaching and learning is based on, providing its indispensable components:

- building meaningful links between learning content and real world;

- activities that are important for students;

- building self-regulating learning;

- cooperation that allows detection of one's own potential strengths and weaknesses;

- development of critical and creative thinking;

- concern for the interests, aptitudes and abilities of each individual;

- reaching of high standards and attainments in the process of teaching;

- a genuine assessment of the achievements through the presentation and evaluation of student work.

Contextual issues are the primary means of contextual teaching and learning in teaching mathematics. These are the 'real natural' problems, which, on the whole, have no "rules" to solve, but it boils down to knowing certain rules of arithmetic operations and the basic laws of mathematics. F. Zech points out that the student "to be able to solve a problem, he must know adequate terms and rules. He must have already been able to implement certain cognitive abilities, for example to analyze the circumstances, to compare, to establish relations. He must be able to apply heuristic rules "(Zech, 1999: 208).

In this sense, a context is characterized by the following guidelines:

- it contains a problem whose solution "requires" algorithm unknown to students;

- students understand the importance and relevance of the problem;

- even though students cannot immediately solve the problem, and they do not know the algorithm for its solving, they have the knowledge and skills associated with the problem and they are convinced that the problem could be solved by their persistence and hard work.

Taking into account the cognitive characteristics of the students of the basic school cycle which indicate the necessity of visualization in the modeling contextual problems, Zech emphasizes the role of illustrated type tasks: "A good option, especially for younger or students whose reading is weak is to set regular « illustrated tasks", in which the situations are presented as in the comics by which students themselves can formulate multiple tasks. The advantage of such tasks is, in the fact, that students can intensively get into a situation, which is difficult with conventional textual tasks that often go from situation to situation "(Zech, 1999: 231).

Proponents of the contextual approach to mathematics education of the basic school cycle emphasize that learning and teaching students of younger school age at the beginning, is necessary to base on contextual problems, which are solved by implementing mathematical operations, and gradually switch to the use of abstract concepts and definitions.

\subsection{Role, quality and structure of mathematics textbooks}

An important component of the quality of mathematics education of the basic school cycle is the quality of the textbook, which, regardless of the competitiveness of many modern didactic media, in its traditional form still has a dominant role in the initial teaching of mathematics in the Republic of Srpska and neighboring countries. A mathematics textbook used in class teaching is the print medium that needs to be developed and promoted in accordance with modern theories of learning and education, with regard to the fact that 
working with the text is a universal process of familiarizing with information and obtaining it. It is designed in accordance with the principles of expository and inductive strategy.

Expository strategy implies that mathematical content is conveyed primarily by exposure to information or the textbook narrative. The information provided in the form of the text and illustration form a functional unit, while tasks have the function to clarify, illustrate, identify and verify the previously exposed. Most often they are found at the end of a lesson or larger thematic section, as in the classic didactic and methodological apparatus.

By using Inductive strategy which is in a function of the working textbook, teaching content is conveyed through tasks and illustrations, forming a functional unit. Instead of all information to be displayed, tasks direct cognitive activity towards the desired outcomes: the definition of the concept or principle, the performance of the essential characteristics, division into sub-classes, etc. The text should have a role of summarizing, generalizing and making points. The function of the task is more demanding than in the expository strategy, since they convey teaching content and keep the learning process (Pešić, 2009: 42).

Bearing in mind the primary role of a mathematics textbook in achieving good communication with the student, it is necessary that all the parameters of its quality should match with developmental and cognitive characteristics of children who it is intended to. It is primarily about the following parameters:

- the aspect of quality of the content of the textbook, that is to say the compliance of nature of knowledge with the nature, personal needs and interests of its users;

- the aspect of quality of didactic design of the textbook, which is manifested in the providing of effective learning in which priority is thinking and not memorable and formative role in the development of students, with an emphasis on the cognition;

- the aspect of quality of language and media characteristics of the textbook.

Students achieve "communication" with mathematics textbooks in the process of teaching in the basic school cycle through a variety of activities including solving numerical and textual tasks, getting to know the essential features of mathematical concepts, generalizations contents and mathematical rules, performing arithmetic operations and the like.

Apart from students, the textbook has been intensively used by teachers:

- in the planning of the process of teaching (making global, thematic and operational lesson plans);

- in preparing for classes considering its support in dimensioning of content of a teaching unit and establishing connections with close past and future content;

- in indicating the terms and formulations (mathematical concepts and rules) that students need to acquire;

- when selecting tasks for practice and repetition;

- including it as work material in the particular phases of the lesson and so on.

M. Egerić points out that two thirds of teachers study mathematics curriculum in detail before teaching a new unit, while for a third of teachers the curriculum is represented by the textbook used by their students and the textbook is their only literature for the preparation of math classes, because they are not able to provide literature and approved textbooks for the relevant class from different publishers. Students solve problems from the textbook in class or at home, depending on the operational tasks of the unit, which is a good preparation for individual use of textbooks and other professional literature (Egerić, 2008: 51).

Since the current mathematics textbooks for initial education in the Republic of Srpska partially enable achievement of the goals of modern mathematics education, they have certain parameters that describe them, together with their traditional role, as a developmental and formative. Viewed from this perspective, the role of mathematics textbooks is primarily to create conditions for students to construct, independently and in accordance with their capabilities, relevant mathematical knowledge, develop skills, beliefs, habits and so on.

Developmental and formative role of a mathematics textbook in the initial teaching, implies specificities that are expressed and are reflected in their design and practical realization, and are also visible in the results which are shown by A. Pešikan and S. Antić:

- First, the textbook becomes a means for organizing the learning process of the students. This means that the content and structure of textbooks must allow students to learn independently. 
- Second, the textbook must be adapted to learners, their abilities, needs, level of interest, prior knowledge.

- Third, the textbook would have to link the daily life of students with academic knowledge and specific educational goals. Through this, the textbook achieves two functions: the material becomes meaningful to those who learn, because the school knowledge becomes closer to their life and thus students become motivated for learning and intellectual work (Pešikan, Antić, 2007).

- Fourth, a textbook becomes one of the elements in creating teaching situations. Teacher use textbooks more for planning, specifically designed learning situations. The textbook becomes a partner to the teacher in the process of teaching, and not a simple replication of his lectures, because it serves him to provide a richer "educational interaction between students and textbooks, and teachers and students" (Ivić et al., 2003: 12).

- Fifth, the concept of the textbook has now extended meaning. The textbook is not only the basic book from which students learn but also a number of other units, which all together make the textbook set (workbook, atlases, exercise books, resources, etc.) (Pešikan, Antić, 2007 by: Antić, 2009: 29-30).

Regarding the determinants of the quality of a textbook in mathematics in the basic school cycle, research shows that a fundamental indicator of the quality of the textbook of mathematics is the coherence between the nature of mathematical knowledge and the character of the textbook. The most important components of the quality of the textbook, quality of content and quality of its didactic characteristics are, through this compatibility, integrated.

There are many parameters of the quality of the textbook that would answer the requirements of "today" and would be one of the most important mechanisms for ensuring the quality of initial mathematical education, and they are expressed in the following:

- to serve the purpose of active learning;

- to have structure that presupposes successful learning;

- to instruct the user of the textbook to learn;

- to have motivational potential;

- to provide a high level of communication;

- to be appropriate for every student and every environment;

- to serve the purpose of development of higher forms of learning and thought processes;

- to support contextual teaching and learning.

Considering the fact that no textbook can be ideal, M. Dejić lists some guidelines of a good textbook that refer to the following facts:

- The textbook presents the systematized knowledge of the current curriculum.

- The presentation is for students who use the textbook. There are neither vague terms nor complex definitions. The knowledge and experience of students is connected with what they learn. At the level of initial teaching process there are no defining of terms. Terms are formed on the basis of many practical examples and defined by creating reasonable tasks. The level of abstraction of the term is increasing with the process of maturing of students.

- Knowledge is not provided in a declarative way, but it is applied in practice and is further used.

- We must pay attention to the relationship of mathematics to other disciplines of school course.

- Presented knowledge must appear convincing.

- Terms must come out from practice.

- In the textbook there must be tasks to develop interest in mathematics. These are tasks of interesting mathematics tasks from practice, tasks which arouse intellectual curiosity, problem-solving tasks, etc. (Dejić, 2008: 145).

Particularities of the mathematical content and mathematical language in which they are presented result in a textbook which is, in structural terms, significantly different from the textbooks for other subjects of initial teaching process. Theoretically, the classic textbook structure makes difference between the basic body of text and the didactic apparatus, while the modern structure makes difference between system of textual and 
non-textual structural elements, which in a mathematics textbook, are at first glance, difficult to detect. Mathematics textbooks, unlike textbooks for other subjects, are full of tasks that "take up the most space," making it difficult to identify the structural elements of any of these classifications.

LJ. Kocić distinguishes structural elements of the textbook according to the function during the lesson and formulates them as structure elements in a function of presenting the content, structure elements in the function of acquiring the content and more efficient learning, and structure elements in a function of orientation (Kocić, 2001 by: Kovačević, 2009: 57). As elements of the textbook in a function of acquiring the content and more efficient learning, $Z$. Kovačević mentions instructions that explicitly refer to the activity in relation to the text, the instructions that explicitly refer to the activity in connection with graphic material, questions and tasks that point to certain mental activities (calculate, explain, name all, determine, compare and the like), interface instructions that in an imperative mode refer to specific activities out of the textbook and which are recognized in the current mathematics textbooks of the basic school cycle (Kovačević, 2009). In all of these instructions the function of the mathematical task as a structural unit of the textbook is to activate the necessary knowledge, mental processes and abilities and to enable understanding of their quantity and quality on the basis of the insight into the process of solving tasks and the result itself.

To be in the function of contextualization of learning and teaching mathematics textbook should abound in solutions that refer students to the appropriate use of the possibilities of contextual resources in the process of acquiring knowledge. B. Vlahović points out some of the components of textbooks that imply a contextual approach to teaching:

- during the process of acquiring knowledge, learning with the use of textbooks and textbook solutions, students are placed in front of the tasks that presuppose activation of previously acquired knowledge and experience and their inclusion into new knowledge;

- within the process of affirmation of different experiences, different potentials of children in the learning process, students are offered alternative choices, alternative solutions and the content (questions, tasks) in several variants within the text of the textbook;

- content, didactic and methodical textbook solutions ... seek for the modes to meet the needs of students of different learning styles, contemporary textbooks have didactic components that seek to provide a learning one and the same content in different contexts;

- ... the textbook is equipped with instrumentation that require periodic repetitions, checking and systematization of earlier received knowledge and other outcomes;

- ... textbook solutions seek for tasks that contribute to the development, the creation of the context of the environment as a community of students learning in teams and in many ways differ from each other (Vlahović, 2009).

\section{RESEARCH METHODOLOGY}

The aim of this research was to examine the support of standard textbooks to the process of contextualization of learning and teaching mathematics in primary school teaching. In that sense, the current analysis of mathematics textbooks from the second to the fifth grade, and the part of the textbook First volume in the first grade that presented mathematical content (pp. 43-72) that was approved for sale and use by the Ministry of Education and Culture of the Republic of Srpska for 2013/14 school year, was done. It focused on the elements of the contextual approach to teaching and in that sense contextual issues were identified and their representation in relation to other kinds of tasks as well as their representation of contextual problems in relation to the way of their design (images, text, a combination of images and text) was registered.

For data collection descriptive method was used and as a research technique, content analysis was used according to the protocol which was designed based on two criteria: the representation of contextual problems in relation to other kinds of tasks and representation of contextual problems according to the mode of expression.

The unit of analysis was a task which we considered a whole in the textbook by numbering (serial number) specified by the author. The exceptions was the mathematical content for the first grade that was structured so that each page of a textbook was shown as a single image or a sequence of images without numbering, with same verbal and graphic account of all examples of tasks. That is why the full content as the unit of analysis was taken. As a way of expressing of their representation frequencies and percentages were used. 
According to the first criterion contextual and practical problems whose plot springs from the natural and social environment of students are identified and registered into the protocol Since they more or less reflect the real life situation, in the majority of them students are "required" to translate pictorial or verbal description of the relationship between the values during the process of solving problems and express them using the language of mathematics. In contrast to them there are all other kinds of tasks that mathematics textbooks abound with. These are tasks such as "solve", "determine", "calculate", "write", "fill in", "add", "divide", etc.

Other structural part of the protocol "required" identification of modalities of contextual problems with regard to the manner of their expression that is to say the presentation of the situation from an authentic context. Among these there are the tasks of the illustrated type, tasks in which the real situation and the problems that arise from them are represented by a combination of text and illustrations, as well as contextual problems in the form of verbal creations.

\section{RESEARCH RESULTS AND DISCUSSION}

The findings, according to the first criterion of classification, are presented in Table 1. It is obvious that contextual problems prevail in relation to other types of tasks only in the textbook for the first grade $(83.70 \%$ vs. $16.30 \%$ ), which is explained by the specific organization of teaching process and the lack of differentiated subjects. In such conditions, the mathematical content is taught within the subject area My Environment which implies an interdisciplinary approach to teaching and learning mathematics in the context of the school and its environment in which children live. There is a significant reduction in the number of contextual issues in the textbook for the second grade $(38.33 \%)$, which is designed so that the content follow mathematics curriculum and, consequently, does not initiate sufficiently understanding and adopting of mathematical terms within a real context.

Up to the higher grades of the basic school cycle the share of contextual problems in mathematics textbooks gradually decreases in favor of the tasks with dominant mathematical terminology (grade $3: 25.33 \%$ vs. $74.67 \%$; grade $4: 24.78 \%$ vs. $75.22 \%$, grade $5: 17.25 \%$ vs. $82.75 \%$ ). The above results are supported by the methodical requirements that indicate that the process of forming mathematical terms in early school age involves concretization to the purpose of enhancing the performance, and a gradual transition from an action and an iconic representation to the abstract mathematical symbolic language.

Table 1. Contextual problems in relation to other kinds of tasks

\begin{tabular}{|c|c|c|c|c|c|c|}
\hline \hline \multirow{2}{*}{ Grade } & \multicolumn{2}{|c|}{$\begin{array}{c}\text { Contextual } \\
\text { problems }\end{array}$} & \multicolumn{2}{|c|}{ Other kinds of tasks } & \multicolumn{2}{|c|}{ Total } \\
\cline { 2 - 7 } & $\mathrm{f}$ & $\%$ & $\mathrm{f}$ & $\%$ & $\mathrm{f}$ & $\%$ \\
\hline Grade 1 & 77 & 83.70 & 15 & 16.30 & 92 & 100.00 \\
\hline Grade 2 & 184 & 38.33 & 296 & 61.67 & 480 & 100.00 \\
\hline Grade 3 & 152 & 25.33 & 448 & 74.67 & 600 & 100.00 \\
\hline Grade 4 & 171 & 24.78 & 519 & 75.22 & 690 & 100.00 \\
\hline Grade 5 & 139 & 17.25 & 667 & 82.75 & 806 & 100.00 \\
\hline \hline
\end{tabular}

According to the mode of expression, that is to say the design of contextual problems illustrated, combined and textual tasks are represented. Figures about their share in mathematics textbooks from grades 1 to 5 are presented in Table 2.

The domination of illustrated tasks $(84.42 \%)$ in relation to the tasks of combined type $(15.58 \%)$ and the complete absence of textual tasks in the textbook for the first grade is evident, due to the insufficient capacity of children in the field of reading and a low level of understanding of the written tasks. In the second grade textbooks, the share of "clean" illustrated tasks is gradually reduced $(19.02 \%)$ but the visualization is still significantly present in the contextual problems of the combined type $(65.22 \%)$. It is evident that the presence of verbal and contextual problems is less than other types of tasks $(15.76 \%)$.

Up to the higher grades of initial teaching the share of illustrated component in mathematics textbooks is reduced in favor of a textual component (grade 3: illustrated 3.29\%, combined $34.87 \%$, textual $61.84 \%$; grade $4: 3.51 \%$ illustrated, combined $21.05 \%$, textual $75.44 \%$; grade 5 : illustrated $0.00 \%$, combined $25.90 \%$, textual, $74.10 \%$ ), so that it is evident that in the fifth grade textbook there is a complete absence of contextual problems of an illustrated type. 
IJASOS- International E-Journal of Advances in Social Sciences, Vol. III, Issue 8, August 2017

Table 2. Contextual problems according to the mode of expression

\begin{tabular}{|c|c|c|c|c|c|c|c|c|}
\hline \hline \multirow{2}{*}{ Grade } & \multicolumn{6}{|c|}{ Contextual problems } & \multicolumn{2}{|c|}{ Total } \\
\cline { 2 - 9 } & \multicolumn{2}{|c|}{ illustrated } & \multicolumn{2}{c|}{ combined } & \multicolumn{2}{c|}{ textual } & \multicolumn{2}{|c|}{} \\
\cline { 2 - 9 } & $\mathrm{f}$ & $\%$ & $\mathrm{f}$ & $\%$ & $\mathrm{f}$ & $\%$ & $\mathrm{f}$ & $\%$ \\
\hline Grade 1 & 65 & 84.42 & 12 & 15.58 & 0 & 0.00 & 77 & 100.00 \\
\hline Grade 2 & 35 & 19.02 & 120 & 65.22 & 29 & 15.76 & 184 & 100.00 \\
\hline Grade 3 & 5 & 3.29 & 53 & 34.87 & 94 & 61.84 & 152 & 100.00 \\
\hline Grade 4 & 6 & 3.51 & 36 & 21.05 & 129 & 75.44 & 171 & 100.00 \\
\hline Grade 5 & 0 & 0.00 & 36 & 25.90 & 103 & 74.10 & 139 & 100.00 \\
\hline \hline
\end{tabular}

\section{CONCLUSION}

Summing up the overall results of theoretical and empirical research on the structure and quality of mathematics textbooks in terms of contextualization of learning and teaching, and in accordance with their role in fostering and creating contextual approach to program content of mathematics, we come to the following relevant conclusions:

Different models of contextual problems, primarily with regard to different forms of expression and presentation (illustrated, textual, combined - picture, text) were identified in mathematics textbooks from the first to the fifth grade.

Their part in the textbooks, and thus in the initial mathematics education is the largest in the first grade due to the dominance of experiential learning and the need for the formation of mathematical terms in a number of practical examples and in real situations that allow the activation of previously acquired knowledge and experience and their inclusion into the new knowledge.

The presence of an illustrated component in the contextual problems is apparent in the lower grades of the basic school cycle, considering the limitation of a cognitive component in the area of reading, comprehension, analytic and synthetic methods, while at older ages its role decreases in favor of a verbal component.

The current mathematics textbooks in numerous aspects reflect the developmental and formative role because they are with the quality of content and didactic design significantly adjusted to the age characteristics of students, enabling self-learning and partial "convergence" of school knowledge to everyday life, and the realization of high-quality interaction with the teacher, although at a large number of educators their application in the teaching process is still reduced to their traditional role.

Total numerical indicators at the level of the basic school cycle indicate to unsatisfactory support of standard textbooks to the process of contextualization of learning and teaching mathematics due to the domination of other types of tasks (62.12\%) over the contextual ones (37.88\%).

\section{REFERENCE LIST}

Academy for Educational Development, Retrieved May 04, 2014 from the World Wide Web http://www.niwl.org/pdfs/Context_Learning.pdf

Antić, S. (2009). Savremena shvatanja udžbenika: posledice na konstrukciju i merila kvaliteta. Inovacije u nastavi, vol. XXII, br. 2009/4, 25-39.

Berns, R. G., Erickson, P. M. (2001). Contextual Teahing and Learning: Preparing Students for the New Economy. The Highlight Zone: Research Work No. 5, Columbus: National Dissemination Center for Career and Technical Education, Retrieved May 11, 2014 from the World Wide Web 
http://www.cord.org/.../nccte_highlight05-contextualte...

Čekrlija, B., Đaković, P. (2013). Matematika za 2. razred osnovne škole. Istočno Sarajevo: Zavod za udžbenike i nastavna sredstva.

Dejić, M. (2008). Neki aspekti obrazovanja učitelja u oblasti metodike nastave matematike. Nastava i vaspitanje, vol. 57, br. 2, 136-149.

De Lange, J. (1987). Mathematics, insight and meaning: Teaching, learning andtesting of mathematics for the life and social sciences. Utrecht: OW \& OC.

Dewey, J. (1963). Experience and Education, The Kappa Delta Pi Lecture Series. New York: Macmillan Publishing Company.

Egerić, M. (2008). Kvalitet nastave matematike u početnim razredima osnovne škole. Inovacije u nastavi, vol. 21, br. 2, 51-59.

Zech, F. (1999). Grundkurs Mathematikdidaktik - Theoretische und praktische Anleitungen für das Lehren und Lernen von Mathematik. Weinheim und Basel: Beltz Verlag.

Ivić, I. et al. (2003). Kvalitet školskih udžbenika i mehanizmi obezbeđivanja tog kvaliteta. Beograd: Obrazovni forum.

Johnson, E. B. (2002). Contextual teaching and learning: what it is and why it's here to stay, Thousand Oaks, CA: Corwin Press, INC.

Kamenov, E., Spasojević, P. (2013). Prva knjiga za 1. razred osnovne škole. Istočno Sarajevo: Zavod za udžbenike i nastavna sredstva.

Kocić, LJ. (2001). Didaktičko-metodički zahtevi u oblikovanju strukture udžbenika, Savremeni osnovnoškolski udžbenik. Beograd: Zavod za udžbenike i nastavna sredstva.

Kovačević, Z. (2009). Instrukcije za samostalno učenje kao strukturalne komponente učenja. Inovacije u nastavi, vol. XXII, br. 2009/4, 56-70.

Lipovac, D. (2013). Matematika za 3. razred osnovne škole. Istočno Sarajevo: Zavod za udžbenike i nastavna sredstva.

Lipovac, D. (2013). Matematika za 4. razred osnovne škole. Istočno Sarajevo: Zavod za udžbenike i nastavna sredstva.

Mićić, B. (2013). Matematika za 5. razred osnovne škole. Istočno Sarajevo: Zavod za udžbenike i nastavna sredstva.

Pešić, J. (2009). Podrška učenju s razumevanjem i strategije didaktičkog oblikovanja udžbenika. Inovacije u nastavi, vol. XXII, br. 2009/4, 40-49.

Pešikan, A., Antić, S. (2007). Kako ugraditi ideje aktivnog učenja u udžbenik. Nastava i istorija, vol. V, br. 7, 147-161.

Rogers, A., Weinbaum, A. (1995). Contextual Learning: A Critical Aspect of School-to-Work Transition Programs. Washington, New York: National Institute for Work and Learning.

Verbitsky, A. A. (1991). Aktivnoye obucheniye v vysshey shkole: kontekstnyj podhod, Active Teaching in College: Contextual Approach. Moscow: Vysshaya shkola.

Vlahović, B. (2009). Udžbenik u susret sutrašnjici obrazovanja. u N. Potkonjak, Buduća škola - zbornik radova sa naučnog skupa II deo, štampano u cjelini, 23-24. januara 2009, Beograd, 1090-1109. Beograd: Srpska akademija obrazovanja. 